The Korean Journal of Helicobacter and Upper Gastrointestinal Research

Vol. 12, No. 3, 151-157, September 2012 • http://dx.doi.org/10.7704/kjhugr.2012.12.3.151

\title{
위식도 접합부 암의 치료
}

\section{Treatment of Adenocarcinoma of the Esophagogastric Junction}

\section{So Yeon Kim, Kyoung Oh Kim}

Department of Internal Medicine, Hallym University Sacred Heart Hospital, Anyang, Korea

In recent years, the incidence of adenocarcinoma of the esophagogastric junction (AEJ) is increasing in the western world, despite of decreasing trend of distal gastric cancer, and the prognosis of $A E J$ remains poor. The appropriate classification of AEJ is important for selecting the optimal surgical approach and making better prognosis. According to Siewert's classification, distal esophageal cancers (type I) are distinguished from true cardia cancers (type II) and subcardiac gastric cancers (type III). Until now, surgical resection with lymphadenectomy based on Siewert's classification has been the mainstay of treatment for all resectable AEJ. Except surgical approach, therapy strategies for AEJ include endoscopic ablation or endoscopic mucosal resection, endoscopic submucosal dissection, neoadjuvant or adjuvant therapy in combination with surgery, and palliative procedures such as stent, laser, photodynamic therapy. A multidisciplinary approach is necessary for optimal management of $A E J$. In this article, we review the treatment options for AEJ including a tailored surgical approach. (Korean J Helicobacter Up Gastrointest Res 2012;12:151-157)

Key Words: Adenocarcinoma of the esophagogastric junction; Surgery; Drug therapy; Radiotherapy; Endoscopic therapy
한림대학교성심병원 소화기내과

김소연, 김경오

\section{서 론}

최근 서구에서 위암의 빈도는 감소하고 있는 반면, 위식 도 접합부 암(adenocarcinoma of the esophagogastric junction, $\mathrm{AEG}$ )의 빈도는 증가하고 있다. ${ }^{1}$ 이러한 위식도 접합부 암 은 그 중심이 해부학적으로 분문부로부터 근위부 및 원위 부 $5 \mathrm{~cm}$ 내에 위치하는 것으로 정의하며, Siewert 분류 기준 에 따라 세 가지로 분류한다. Type I은 식도의 바렛식도와 같은 식도의 장상피화생이 일어난 곳에서 주로 발생하는 원위부 식도암이며, type II는 분문부의 상피 또는 위식도 접합부의 장상피화생이 일어난 부분에서 발생하는 분문부 암이고, type III는 아래쪽으로부터 위식도 접합부와 원위부
식도를 침범하는 하부 분문부 암이다. ${ }^{2,3}$

저자에 따라 위식도 접합부 근처의 암을 식도암, 혹은 위 암, 아니면 식도나 위암과 다른 별개의 암으로 구분하여 기 술하는 경우가 있는데, The New International Union Against Cancer에서 발표한 7판 TNM 병기체계에 의하면 위식도 접 합부 $5 \mathrm{~cm}$ 이내에 종양의 중심이 존재하고 식도 쪽으로 종 양이 퍼진 경우는 식도암으로 고려하여 치료해야 하고, 위 식도 접합부로부터 $5 \mathrm{~cm}$ 이상 떨어져서 종양의 중심이 위 쪽에 있는 경우, 혹은 위식도 접합부로부터 $5 \mathrm{~cm}$ 이내에 종 양의 중심이 위치하나 식도 쪽으로 퍼지지 않은 경우는 위 암으로 고려하여 치료해야 한다.

병기에 따라 적절한 치료계획이 달라지기 때문에 치료 전 병기설정이 중요한데, 이는 TNM 분류시스템에 따른다. 
이때 T, N은 내시경 초음파(endoscopic ultrasound)로 종양의 침범 깊이를 파악하여 나누고, 종양의 전신 전이여부는 computed tomography scan이나 positive electron tomography 등의 검사결과에 따른다.

\section{본 론}

위식도 접합부 암의 치료에는 식도 절제술(esophagectomy) 등의 수술적 치료와 내시경적 열 치료술(endoscopic ablation), 또는 내시경적 절제술(endoscopic mucosal resection, endoscopic submucosal dissection)과 같은 내시경적 치료, 수술 전후의 방사선 또는 방사선 항암요법(neoadjuvant/adjuvant [radio] chemotherapy), 그 외 스텐트나 레이저, 광역동치료(photodynamic therapy, PDT)를 이용한 고식적 치 료 등이 있다. ${ }^{4}$

\section{1. 수술적 방법}

원격전이가 없고 수술적 절제가 가능한 위식도 접합부 암의 치료는 수술적 절제가 원칙이다. 절제 시 종양과 그 종양의 배액 림프절을 모두 절제하는 것이 생존율을 높일 수 있다. 현재까지는 조기(T1a)의 위식도 접합부 암에서의 수술적 치료만이 국제적인 표준적 치료로 인정되고 있다.

하지만, 점막하층을 침범하지 않는 점막의 종양인 $\mathrm{Tla}$ 에 서는 내시경적 점막 절제술 및 열 치료술 혹은 식도 절제술 을 고려하며, 점막하층을 침범한 $\mathrm{T} 1 \mathrm{~b}$, 혹은 더 깊이 침범한
종양에서는 식도 절제술을 시행한다. 또한, T1-T3 종양에서 는 국소적인 림프절 전이가 있어도 절제가 가능하나, 종양 이 크거나 다발적으로 림프절을 침범한 경우는 상대적인 수술의 금기증이 될 수 있다. 그러므로 최종적으로 환자의 나이와 전신 활동도를 고려해서 결정해야 하고, 심낭막, 흉 막 또는 횡경막을 침범한 $\mathrm{T} 4$ 종양에서도 침범장기를 포함 하여 일괄 절제할 수 있다면 절제술을 시행해 볼 수 있다.

1) 수술 접근법: 경흉부 식도위절제술(transthoracic esophagogastrectomy), 경열공 식도위절제술(transhiatal esophagogastrectomy), 경흉부 또는 흉복부 식도위절제술(transthoracic or thoracoabdominal esophagogastrectomy), 최소침습적 식 도절제술(minimally invasive esophagectomy)과 같은 접근법 을 사용한다. 이중 가장 흔히 사용되는 수술 접근법은 경흉 부 또는 경열공 식도, 위 절제술로, 경향부 및 경열공 접근 법을 비교한 연구 결과 R0 절제율은 $72 \%$ vs. $71 \%(P=0.28)$ 로 비슷했으나 수술 시 평균 림프절 절제 개수는 16 vs. 31 $(P<0.001)$ 이었고, 입원 중 사망률은 두 그룹이 큰 차이 없 는 것으로 보고되었다. ${ }^{5}$ 년 무병 생존율은 경흉부 접근법 에서 더 좋지 않은 결과를 보였으며, 최소 5년 이상 추적 관찰한 결과 5년 생존율은 두 접근법이 큰 차이가 없었다 $(P=0.69)$.

2) 분류법에 따른 수술방법: 현재까지 많은 외과의사들은 주로 Siewert 분류에 따른 수술적 치료법을 사용해왔으며, type I과 II의 위식도 접합부 암은 식도절제술을 시행하나, type III의 경우는 위암에서의 수술법을 적용해야 한다고 알

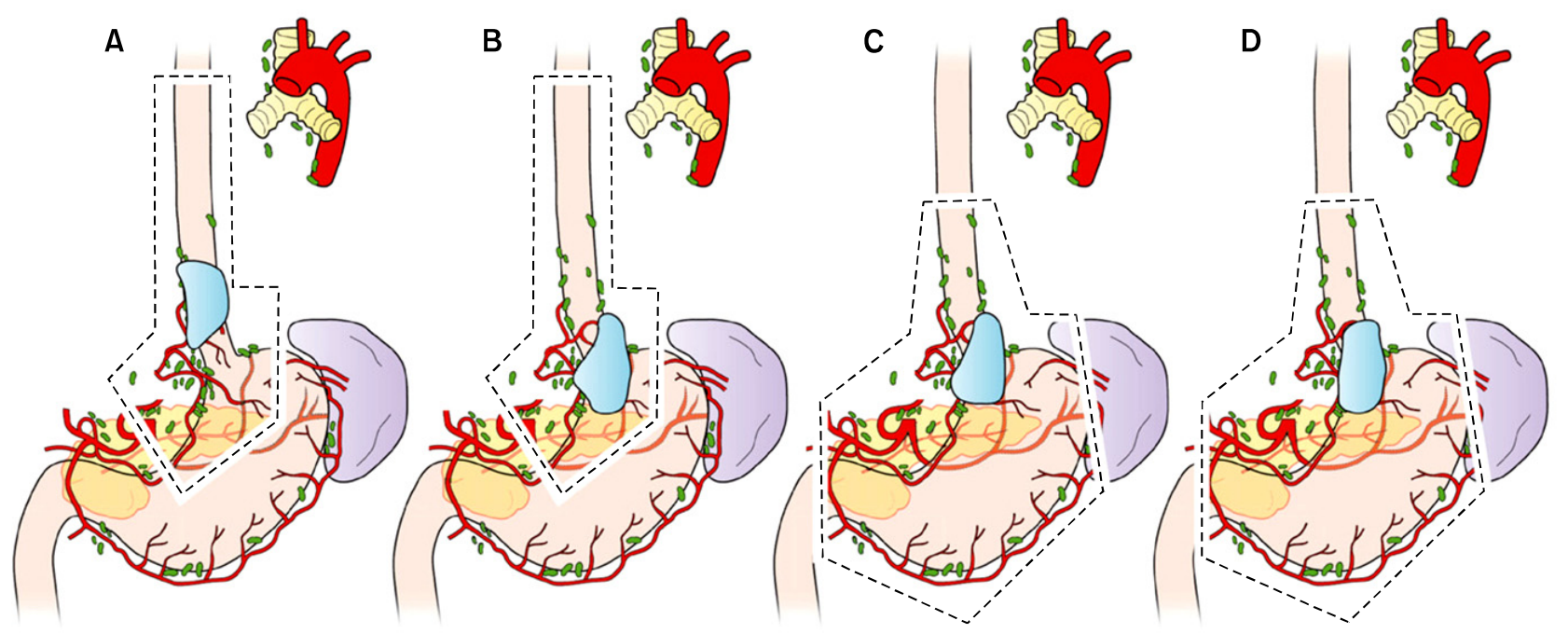

Fig. 1. Extent of surgical resection of esophagogastric junction cancer according to Siewert's classification. (A) Type I (subtotal esophagectomy with proximal gastrectomy), (B) type II (subtotal esophagectomy with proximal gastrectomy), (C) type II (total gastrectomy with distal esophagectomy), (D) type III (total gastrectomy) (Adapted from the article of Gronnier et al. J Visc Surg 2012;149:e23-33 ${ }^{5}$ ). 
려졌다(Fig. 1). ${ }^{3}$

Type I은 원위부 식도암으로, 경흉부 총괄 아전식도절제 술(transthoracic en bloc subtotal esophagectomy)과 근위부 위 절제술(proximal gastrectomy)을 시행한다. 식도의 근위부 절 제연은 최소 $8 \mathrm{~cm}$, 원위부 절제연은 최소 $5 \mathrm{~cm}$ 가 되어야 하며, 림프절 절제 시에는 two-field 광범위 림프절곽청술이 추천된다. 개흉술의 위험성이 높아 금기인 환자에서는 경 열공 식도절제술을 사용할 수 있으며, 이때는 two-field 림프 절 곽청술과 함께 하부 종격동 림프절 절제술이 시행되어 야 한다. 또한, 술 후 검체에는 최소 23 개의 림프절이 포함 되어 있어야 한다.

Type II는 분문부 암으로, 복부 접근법을 통한 전위절제 술과 부분적 식도절제술(total gastrectomy with partial esophagectomy through an abdominal approach), 혹은 경흉부 또는 경열공 접근법을 통한 근위부 위절제술 및 원위부 식도절 제술(proximal gastrectomy associated with distal esophagectomy through a transthoracic or transhiatal approach)의 둘 중 한 가지를 선택해서 시행한다. 그러나, 앞서 언급했듯이 우 리나라에서는 type III와 같이 전위절제술을 시행하는 것이 좋은 예후를 얻을 수 있다는 보고가 있다. ${ }^{6}$

Type III는 하부 분문부 암이며, 위암의 수술적 치료에 준 해서 시행해야 한다. 수술법은 전위절제술(total gastrectomy)로, 절제연은 근위부 최소 $5 \mathrm{~cm}$, 원위부 최소 $2 \sim 3 \mathrm{~cm}$ 의 여유를 가지고 시행해야 한다. 림프절 제거 시에는 위암 의 경우에서처럼 원위부 비장, 췌장 절제술 및 $\mathrm{D} 2$ 림프절 절제술(D2 lymphadenectomy with distal splenopancreatectomy)을 시행하며, 림프절은 최소 25 개를 포함해야 한다.

Siewert 분류에 따른 수술 방법만을 고려했을 경우, 앞서 언급했던 7th TMN 병기체계에 따라 type III로 분류된 경우 도 식도암에 준해 수술을 진행해야 되므로 이에 대한 논란 이 있을 수 있어, 이와 관련하여 위식도 접합부 암의 적절한 분류법을 판단하기 위한 최근 서울대의 연구 결과가 보고 되었다. TNM 병기체계에 따른 분류법은 Siewert 분류법과 는 달리 T와 N병기를 고려한 분류이고 종양의 깊이, 크기가 림프절 전이와 관련한 $\mathrm{N}$ 병기에 영향을 미치는 주된 요인이 며, 위식도 접합부의 침범 여부는 위식도 접합부 암의 예후 에 영향을 미치지 않는다는 결과를 얻었다. 또한 type II, III 의 예후는 비슷하고 비슷한 임상병리학적 특성을 보여, 두 type 모두 TNM의 위암형 위식도 접합부 암으로 간주하여 치료하는 것이 좋은 예후를 얻을 수 있다고 보고하였다.

또한, 동양과 서양은 위식도 접합부 암의 특성이 다르기 때문에 동양에서는 서양에서의 Siewert 분류에 따른 수술법 과는 달리 동양에서 비교적 흔한 type II, III를 위의 근위부 $1 / 3$ 의 선암의 한 종류로 간주하여 위암의 수술법에 따라 치
료하는 것이 좋으므로, type II, III 둘 다 위식도 접합부의 침범 여부에 관계없이 위암에 준하여 치료해야 한다는 연 구도 발표된 바 있다. ${ }^{78}$ 그러므로 우리나라의 경우 type II와 III의 수술 후 예후는 위암의 수술 후 예후와 비슷하며 식도 암에 준한 식도절제술은 적합하지 않으므로, R0 절제 효과 를 얻기 위해 둘 다 위식도 접합부의 침범 여부에 관계없이 위암에 준하여 치료해야 할 것이다. ${ }^{6,7}$ 이때 우리나라에서는 서양과는 달리 개흉술 없이 복부를 통한 전위절제술 (abdominal total gastrectomy)를 시행하는 것을 권고하고 있 다. ${ }^{6}$

3) 림프절제술 및 비장절제술: 위식도 접합부 암에서 하 부 종격동 림프절 전이 여부가 생존결정의 독립적인 인자 가 될 수 있다는 보고가 있지만, 예방적인 종격동 림프절 절제술은 수술의 위험이 높고 생존율을 향상시키는데 미치 는 영향이 미미하여 논란의 여지가 있었다. ${ }^{911}$ 그러나 최근 에는 하부 후방 종격동(lower posterior mediastinum)에서 복 강동맥(celiac axis)을 따라 광범위 림프절절제술(extended lymphadenectomy)을 시행하는 것이 예후를 향상시키며, 림 프 배액의 양상에 맞춰 림프절 곽청술 시에는 비장동맥을 따라 위치하는 림프절과 비문 및 좌신정맥을 따라 위치하 는 림프절 모두 절제해야 한다고 추천하고 있다. ${ }^{12}$ 또한, 후 복막강에서 림프절 곽청술을 시행할 때는 간혹 비장절제술 과 함께 좌측 췌장 절제술도 시행하는데, 이때 많은 수의 림프절을 절제해야 하므로 췌장루나 췌장 농양, 패혈증 등 의 합병증이 잘 발생할 수 있다. 췌장보존 비장절제술은 췌 장루가 발생하는 위험성을 줄이면서 비슷한 수의 림프절을 절제하는 방법이지만 비장절제술 자체만으로도 심각한 합 병증을 일으킬 수 있다. 그러므로, 비장절제는 림프절 전이 가 확실하거나 비문을 침범한 경우의 환자에서만 시행하는 것이 좋다. ${ }^{12}$

4) 수술의 원칙: 위식도 접합부 암은 종양과 주변 림프절 을 완전히 제거(R0 절제술)하여 국소적 재발을 최소화하는 것이 수술적 치료의 목표이다. ${ }^{4}$ 수술 시 복강 내 세포검사가 양성인 경우는 불량한 예후와 관련이 있으며 이는 M1 병기 로 정의되므로 임상적으로 $\mathrm{T} 3$ 혹은 림프절 전이 양성 $(\mathrm{N}+)$ 의 진행된 위식도 접합부 암을 가지는 환자에서는 복강경 을 이용한 복강세척으로 병기 설정하는 것을 고려해야 하 며 림프절 곽청술은 표준 혹은 광범위(en-bloc) 기법을 사용 해야 한다. R0 절제술(complete macroscopic and microscopic resection)은 R1 절제술(microscopically incomplete resection) 과 R2 절제술(macroscopically incomplete resection)에 비해 생존율을 연장시킬 수 있어 좋은 예후와 연관이 있다. 위식 도 접합부 암에서 림프절 침범 여부는 주된 예후인자이며, 국소적 혹은 원격 재발의 예측인자이기도 하다. 그러므로, 
림프절 곽청술은 암의 병기설정, 국소적 재발 확률 감소, 그 리고 생존율 향상에 중요한 역할을 한다. 일괄적 총 근위부 식도위절제술(en bloc radical proximal esophagogastrectomy) 을 시행할 때 복부 쪽 절제는 좌우 para-cardial, 좌측 소만, 그리고 복강 신경총 주변의 림프절을 포함해야 한다. 유도 방사선 항암치료 없이 식도절제술만 시행받는 사람은 적절 한 림프절 병기설정을 하기 위해 최소 15 개의 림프절을 제 거하여 확인해야 하며, 술 전 방사선 항암치료 후의 치료 적절성 확인을 위한 림프절 수는 아직 알려지지 않았지만 동일한 개수의 림프절 절제가 추천되고 있다. ${ }^{12}$

\section{2. 내시경적 치료}

Siewert 분류에 따르는 수술적 치료가 제시되기 전, 수년 동안 위식도 접합부 암의 주된 치료원칙은 전위절제술 및 경열공 원위부 식도절제술이었다. 이는 과치료를 할 수 있 는 위험이 있으며, 술 후 환자의 삶의 질을 낮출 수 있어 조기 위식도 접합부 암 환자에서 이러한 광범위한 절제가 필요한지에 대한 의문이 제기되어 왔다. 이러한 조기 위식 도 접합부 암 환자에서 내시경적 치료가 고려될 수 있는데, 그 중 고분화도 이형성증의 병변이나 Tis 병기의 병변은 점 막에 결절성 변화가 있는지, 측방으로 퍼져있는지, 또는 다 발성 병변인지를 확인 후 내시경적 절제술, 광역동치료, 고 주파열치료(radiofrequency ablation), 혹은 냉동요법(cryoablation) 등의 방법을 이용할 수 있다.

1) 내시경적 절제술: The National Comprehensive Cancer Network guideline에 따르면 Tis 혹은 T1a 종양에서는 내시 경적 점막 절제술(endoscopic mucosal resection, EMR)을 치 료방법으로 추천하며, 이 중 $\mathrm{Tla}$ 는 암이 림프절 전이나 혈 관의 침범 없이 점막고유층(lamina propria) 또는 점막근판 (muscularis mucosae)에 국한되어 있는 것으로, full-thickness 내시경적 점막절제술로 치료할 수 있다. 내시경적 점막 절 제술의 궁극적 목적은 조기암을 제거하고 바렛병변을 잘라 내는 것으로, 절제의 범위가 점막하층과 점막근판(muscularis mucosae)이기 때문에 치료 전 정확한 종양의 침범 깊이 와 병기 설정이 필수적이다.

점막에 국한된 종양이 표재성 $(\mathrm{m} 1$ or $\mathrm{m} 2)$ 인 경우에 림프 절 침범 가능성은 거의 없으며, 좀 더 깊은 경우(m3)에서도 가능성은 거의 $0 \%$ 이다. 그러나, 점막하층의 위쪽 $1 / 3$ 의 종 양 $(\mathrm{sm} 1)$ 에서 림프절 침범은 1 3\%이고, 좀 더 깊은 점막하 종양(sm2 and sm3)에서는 10 30\%만큼 높아진다. ${ }^{13}$ 그래서 superficial in situ adenocarcinoma (T1-m1-m3 and T1sm1)은 직경이 $2 \mathrm{~cm}$ 보다 작고, 궤양이 없는 경우 내시경적 점막하 층 박리술(endoscopic submucosal dissection, ESD)로 치료해 볼 수 있다. ${ }^{5}$ 그러나, 조직학적으로 조금 더 깊은 $\mathrm{sm} 2$ 혹은 $\mathrm{sm} 3$ 종양에서는 림프절 전이 가능성이 높으므로 내시경적 치료 보다는 식도절제술이 권고되어야 한다. 최근 점막하 층을 침범하지 않고 분화도가 좋은 $2 \mathrm{~cm}$ 이하의 위식도 접 합부 암에서는 수술을 계획하기 전에 종양의 병리를 평가 하기 위해 먼저 내시경적 점막하층 박리술을 시행해 보는 것이 보다 덜 침습적이며, 수술이 꼭 필요한지 평가하기 위 한 진단목적으로도 좋을 것이라 제시하는 논문이 발표되기 도 했다. ${ }^{14}$

그 외 내시경을 이용한 en bloc mucosectomy resection을 시행할 경우 정확한 조직학적 분석이 가능하며, 바렛식도 의 이형성 점막과 관련한 경우에도 사용할 수 있다. ${ }^{4}$

내시경적 치료 5 6주 후 내시경을 이용한 생검와 솔질 세포검사(brushing)로 치료 여부를 평가해야 하고, Tis 혹은 $\mathrm{Tla}$ 의 조기 암에서 내시경적 점막 절제술 후 내시경 추적관 찰은 첫 일 년 동안 3 개월마다, 그 후에는 매년 지속되어야 한다. ${ }^{12}$

2) PDT: 광역동치료는 바렛식도의 이형성증과 위식도 접 합부 암의 병변을 제거하는 데에 효과적으로 사용되어 왔 으나, 시술 후의 점막 손상의 깊이가 부정확하고 그 정도를 예측하는 것이 불가능하며, 조직이 손상되어 병리검사를 위한 검체를 얻을 수 없기 때문에 종양이 모두 제거되었는 지의 여부를 확인할 수 없다는 단점이 있다. 또한 시술 후 재발과 협착 가능성이 높으며, 림프절 전이가 있을 경우 이 에 대한 치료를 할 수가 없다. ${ }^{4}$ 이 외에도 식도절제술 등의 수술비용보다 비싸다는 단점이 있어, 바렛식도의 이형성증 이나 암이 발견되었을 때의 모든 경우에 관례적으로 적용 하기 어렵다. 최근에는 내시경적 절제술에 광역동치료를 추가적으로 시행할 때 내시경적 점막절제술 후의 재발을 줄일 수 있다고 보고된 바 있다. ${ }^{15}$

3) Radiofrequency: 바렛식도와 관련한 이형성 병변을 파 괴하는데 이용될 수 있다고 하며, 낮은 협착률(6\%)을 가진 다. ${ }^{16}$

\section{Multimodal therapy}

1) 전보조치료와 수술적 절제(neoadjuvant therapy followed by surgical resection): 종양의 크기가 크고 이미 진행 된 경우에는 수술에 부가적으로 술 전 항암 치료 또는 방사 선 항암 요법을 시행해 볼 수 있다. 최근 meta-analysis에서 술 전 항암치료는 추적관찰 후 수술만 단독으로 시행한 경 우에 비해 2년 무병 생존율(disease-free survival rate) 및 생존 율(overall survival rate)을 거의 $7 \%$ 정도 향상시키고, 종양의 전이 재발률도 감소시킬 수 있다고 보고했다. ${ }^{1718}$ 또한 다른 연구에서는 술 전 방사선 항암 요법이 수술 단독 치료에 비해 5년 무병 생존율 및 생존율을 향상시킬 수 있다고 보고 
했다. ${ }^{18,19}$ 특히 술 전 방사선 항암요법을 시행한 경우에서는 통계적으로 R0 절제 가능성을 유의하게 높였다. 지금까지 보고된 연구 결과를 종합했을 때, 술 전 방사선 항암요법은 수술 시 R0 절제 가능성을 높여주며, 근위부로 퍼지는 국소 적, 진행성 위식도 접합부 암을 가진 환자의 생존율을 높여 준다. 그러나 I 또는 II 병기의 암을 가진 환자에서는 술 전 방사선 항암요법이 도움이 되지 않는다.

최근 독일에서 발표된 무작위 연구결과에서, 술 전 유도 항암요법 후 방사선 항암요법을 시행하는 경우와 술 전 항 암요법만 시행하는 경우를 비교하였는데, 이 둘은 R0 절제 가능성은 비슷했으나, 약 45.6개월 추적관찰 후 전자의 경 우에서 병리학적 완전 관해(complete histological response)가 의미 있게 높았고( $10.2 \%$ vs. $2 \%, P=0.03), 3$ 년 생존율 또한 향상되었다 $(47.7 \%$ vs. $27.7 \%, P=0.07){ }^{20}$

2) 수술 후 보조요법(adjuvant therapy): 진행된 위식도 접 합부 암에서 술 후 항암치료는 수술 단독에 비해 5년 생존 율 향상은 매우 미미한 정도이다. ${ }^{21}$ 술 후 방사선 항암요법 은 술 전 병합치료 없이 수술을 진행한 뒤 재발할 위험도가 높은 환자들에서 시행해 볼 수 있다.

3) 수술 중 항암 보조요법(periopertive chemotherapy/chemoradiotherapy): 위식도 접합부 암 환자의 약 $70 \%$ 에서 복 막, 간, 횡경막 등의 원격전이를 할 수 있다고 보고되어 있 어, 이와 관련한 수술적 치료의 한계점을 보완하기 위해 수
술 중 항암 보조요법에 대한 연구가 많이 진행되고 있 다. ${ }^{22-24}$ 영국의 The Medical Research Council Adjuvant Gastric Infusional Chemotherapy trial에서는 수술 중에 cisplatin을 기 반으로 한 epirubicin, cisplatin, infused fluorouracil (ECF) 항 암 요법을 시행한 결과, 수술 단독 요법에 비해 생존율을 향상시킬 수 있었다고 보고된 바 있어 위식도 접합부 암의 수술적 치료 시에 방사선 항암 요법을 병행하는 것이 고려 될 수 있다. 23,24

4) 표적치료(targeted therapy): Epidermal growth factor receptor (EGFR), vascular endothelial growth factor receptor (VEGFR), epidermal growth factor receptor 2 gene (HER2-neu) 의 과발현은 환자의 불량한 예후와 연관된 것으로, 임상실 험에서 cetuximab과 erlotinib과 같은 EGFR inhibitor와 trastuzumab (anti-HER2 antibody), bevacizumab (anti-VEGFR antibody)이 진행된 위식도 접합부 암 환자의 치료로 고려되고 있다. ${ }^{12}$

5) 진행된 위식도 접합부 암에서의 항암요법: 진행된 선 암에서는 cisplatin을 기반으로 한 전신항암요법이 일차치료 로 권고되는데, HER2-neu의 과발현이 있는 경우 trastuzumab을 cisplatin과 fluoropyrimidine과 함께 투약할 수 있으며, 그 외 fluorouracil과 cisplatin을 기반으로 한 전신 항암요법 인 ECF 항암 요법과 docetaxel, cisplatin, fluorouracil (DCF) 항암 요법이 치료반응을 높이고 생존율을 향상시킬 수 있

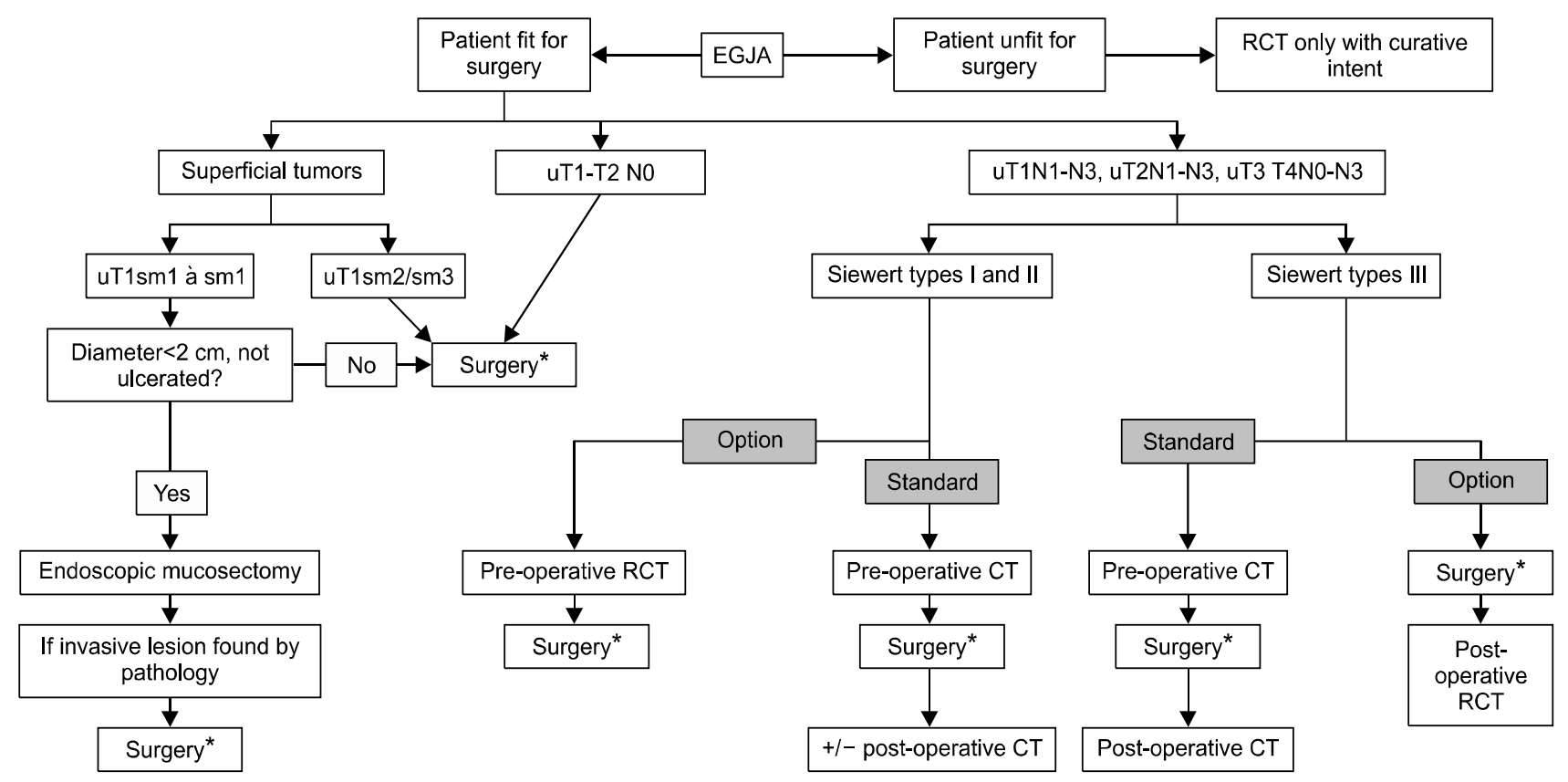

Fig. 2. Algorithm for management of esophagogastric junction adenocarcinoma (EGJA). RCT, radiation chemotherapy; CT, chemotherapy. Surgery*: type I esophagectomy, type II proximal esogastrectomy or total esogastrectomy, type III total gastrectomy; surgery is always associated with lymphadenectomy (Adapted from the article of Gronnier et al. J Visc Surg 2012;149:e23-335). 
다고 보고된 바 있다. ${ }^{12,25-27}$

위와 같은 내용을 종합하여, 위식도 접합부 암의 병기에 따라 그림과 같은 치료 계획을 세울 수 있다(Fig. 2).

\section{결 론}

위식도 접합부 암은 최근 증가하는 추세로, 이에 대한 적 절한 치료계획을 세우는 것이 중요하다. 위식도 접합부 암 은 주로 두 가지 이상의 치료법을 병합해서 시행하는 경우 가 많지만, 여전히 절제 가능한 암의 경우는 수술적 절제가 주된 치료이다. 또한, 병합치료의 경우 술 전 병합치료가 술 후 방사선 항암요법보다 생존율을 향상시킨다고 보고되어 술 전 방사선항암요법의 역할과 치료 적응증에 대한 정립 이 필요하며, 그 외 수술보다 덜 침습적인 내시경적 치료나 표적치료에 대해서도 보다 많은 연구가 필요하다.

\section{참 고 문 헌}

1. Pera M, Cameron AJ, Trastek VF, Carpenter HA, Zinsmeister AR. Increasing incidence of adenocarcinoma of the esophagus and esophagogastric junction. Gastroenterology 1993;104:510-513.

2. Siewert JR, Stein HJ. Classification of adenocarcinoma of the oesophagogastric junction. Br J Surg 1998;85:1457-1459.

3. Siewert JR, Stein HJ, Sendler A, Fink U. Surgical resection for cancer of the cardia. Semin Surg Oncol 1999;17:125-131.

4. DeMeester SR. Adenocarcinoma of the esophagus and cardia: a review of the disease and its treatment. Ann Surg Oncol 2006; 13:12-30.

5. Gronnier C, Piessen G, Mariette C. Diagnosis and treatment of non-metastatic esophagogastric junction adenocarcinoma: what are the current options? J Visc Surg 2012;149:e23-33.

6. Kim KT, Jeong O, Jung MR, Ryu SY, Park YK. Outcomes of abdominal total gastrectomy for type II and III gastroesophageal junction tumors: single center's experience in Korea. J Gastric Cancer 2012;12:36-42.

7. Suh YS, Han DS, Kong SH, et al. Should adenocarcinoma of the esophagogastric junction be classified as esophageal cancer? A comparative analysis according to the seventh AJCC TNM classification. Ann Surg 2012;255:908-915.

8. Hasegawa S, Yoshikawa T, Cho H, Tsuburaya A, Kobayashi O. Is adenocarcinoma of the esophagogastric junction different between Japan and western countries? The incidence and clinicopathological features at a Japanese high-volume cancer center. World J Surg 2009;33:95-103.

9. Nakamura M, Iwahashi M, Nakamori M, et al. Lower mediastinal lymph node metastasis is an independent survival factor of Siewert type II and III adenocarcinomas in the gastroesophageal junction. Am Surg 2012;78:567-573.

10. Maruyama K, Sasako M, Kinoshita T, Sano T, Katai H. Surgical treatment for gastric cancer: the Japanese approach. Semin Oncol
1996;23:360-368.

11. Kodama I, Kofuji K, Yano S, et al. Lymph node metastasis and lymphadenectomy for carcinoma in the gastric cardia: clinical experience. Int Surg 1998;83:205-209.

12. Jaffer AA, David JB, Stephen B, Thomas A. Esophageal and esophagogastric junction cancers. National Comprehensive Cancer Network Practice Guidelines in Oncology 2012. http://www.ncen. org/professionals/physician_gls/f_guidelines.asp.

13. Hölscher AH, Drebber U, Mönig SP, Schulte C, Vallböhmer D, Bollschweiler E. Early gastric cancer: lymph node metastasis starts with deep mucosal infiltration. Ann Surg 2009;250:791-797.

14. Omae M, Fujisaki J, Horiuchi Y, et al. Safety, efficacy, and long-term outcomes for endoscopic submucosal dissection of early esophagogastric junction cancer. Gastric Cancer 2012. [Epub ahead of print]

15. Buttar NS, Wang KK, Lutzke LS, Krishnadath KK, Anderson MA. Combined endoscopic mucosal resection and photodynamic therapy for esophageal neoplasia within Barrett's esophagus. Gastrointest Endosc 2001;54:682-688.

16. Okines AF, Norman AR, McCloud P, Kang YK, Cunningham D. Meta-analysis of the REAL-2 and ML17032 trials: evaluating capecitabine-based combination chemotherapy and infused 5-fluorouracil-based combination chemotherapy for the treatment of advanced oesophago-gastric cancer. Ann Oncol 2009;20:1529-1534.

17. Thirion PG, Michiels S, Le Maitre A, Tierney J; Meta Analysis of Chemotherapy in Esophagus Cancer Collaborative Group. Individual patient data-based meta-analysis assessing preoperative chemotherapy in resectable oesophageal carcinoma. Proc Am Soc Clin Oncol 2007;25:18(Suppl):4512.

18. Gebski V, Burmeister B, Smithers BM, Foo K, Zalcberg J, Simes J; Australasian Gastro-Intestinal Trials Group. Survival benefits from neoadjuvant chemoradiotherapy or chemotherapy in oesophageal carcinoma: a meta-analysis. Lancet Oncol 2007;8:226-234.

19. Thirion P, Maillard E, Pignon J. Individual patient data-based meta-analysis assessing the effect of preoperative chemo-radiotherapy in resectable esophageal carcinoma. Int $\mathrm{J}$ Radiat Oncol Biol Phys 2008;72:S71-S72.

20. Stahl M, Walz MK, Stuschke M, et al. Phase III comparison of preoperative chemotherapy compared with chemoradiotherapy in patients with locally advanced adenocarcinoma of the esophagogastric junction. J Clin Oncol 2009;27:851-856.

21. Falcone A. Future strategies and adjuvant treatment of gastric cancer. Ann Oncol 2003;14 Suppl 2:ii45-ii47.

22. Sasako M, Sano T, Yamamoto S, et al; Japan Clinical Oncology Group (JCOG9502). Left thoracoabdominal approach versus abdominal-transhiatal approach for gastric cancer of the cardia or subcardia: a randomised controlled trial. Lancet Oncol 2006;7:644651.

23. Cunningham D, Allum WH, Stenning SP, et al. Perioperative chemotherapy versus surgery alone for resectable gastroesophageal cancer. N Engl J Med 2006;355:11-20.

24. May KS, Yang GY, Khushalani NI. The role of radiation in the perioperative treatment of esophagogastric cancer. Curr Treat Options Oncol 2011;12:61-71.

25. Wagner AD, Grothe W, Haerting J, Kleber G, Grothey A, Fleig 
WE. Chemotherapy in advanced gastric cancer: a systematic review and meta-analysis based on aggregate data. J Clin Oncol 2006;24:2903-2909.

26. Van Cutsem E, Moiseyenko VM, Tjulandin S, et al; V325 Study Group. Phase III study of docetaxel and cisplatin plus fluorouracil compared with cisplatin and fluorouracil as first-line therapy for advanced gastric cancer: a report of the V325 Study Group. J Clin Oncol 2006;24:4991-4997.

27. Cunningham D, Starling N, Rao S, et al; Upper Gastrointestinal Clinical Studies Group of the National Cancer Research Institute of the United Kingdom. Capecitabine and oxaliplatin for advanced esophagogastric cancer. N Engl J Med 2008;358:36-46. 